\title{
The Al-Qur'an Education-Based Curriculum at PAUD IT Sunnah Annajah
}

\author{
Mahara Suardi 1,*, Rudiyanto ${ }^{2}$ \\ ${ }^{1,2}$ Department of Early Childhood Education, School of Postgraduate, Universitas Pendidikan Indonesia \\ *Corresponding author. Email: maharasuardi21@upi.edu
}

\begin{abstract}
PAUD IT Sunnah Annajah, which is located in Central Aceh District, Aceh Province, has children aged 5 and 6 who attend Kindergarten B when they graduate and are able to memorize 1 juz of the Quran, which is 30 chapters consisting of 36 letters. The very early age of children is not easy. However, PAUD IT Sunnah Annajah's children have the advantage of being able to memorize them. Based on this, this article aims to see how the implementation of the Quranbased educational curriculum in PAUD IT Sunnah Annajah. This study used a phenomenological qualitative research method with the types of data that the researcher had obtained were analysed using data reduction, data presentation and conclusion drawing. The results of this study are expected to provide information about the implementation of the Quran memorization program for early childhood education and provide further programs.
\end{abstract}

Keywords: Al- Qur'an curriculum, early childhood, teacher strategy.

\section{INTRODUCTION}

The curriculum has a very high position in education, because it is a tool to achieve a vision, mission and goals to be achieved by an institution. Al-Qur'an educationbased curricula in Early Childhood Education institutions provide complete opportunities for institutions to carry out curriculum development as a process carried out by several or all members of educational institutions who plan, implement, and evaluate one or more aspects of the curriculum. This process is carried out selectively, adaptively, and creatively. The Al-Qur'an-based educational curriculum has the goal of elevating character, respecting spiritual and human values, teaching honest and moral behaviour, and preparing students to live a simple and clean heart [1]. Described by Saifuddin [2] that the Al-Qur'an-based curriculum is a tool to achieve educational goals as well as a guide in the implementation of education. Prabowo [3] added supporting factors for the implementation of the Qur'anbased curriculum, namely; the existence of school policies, teachers, facilities and infrastructure. Islamic education institutions aim to form a generation of believers, virtuous, broad-minded and social Muslims [4]. One of the important components in the delivery of education is how the curriculum is organized in educational institutions [5]. By establishing the curriculum, it means that the planning process is divided into two stages, namely the analysis of future needs and the determination of ongoing programs [6].
In the research conducted Nasir (2009) according to him, in Indonesia the decentralization of education or regional autonomy provides a new atmosphere in the management and development of Al-Qur'an based or madrasah-based curricula, which includes changes in the transfer of responsibility for decision making or curriculum development from the central government to the authority of each institution. So that with this policy, school or institution-based curriculum development involves several things such as; teacher participation in decision-making related to the development and implementation of the institutional curriculum, participation of all institutional components including heads of institutions, teachers, staff, communities, students, etc., and creative, innovative, and creative institutional development adaptive [7].

Curriculum development in PAUD educational institutions must be adjusted to the Standards for Child Development Achievement Level (STPPA) as stated in Permendikbud No.137 of 2014. Based on these guidelines it can be said that children aged 5-6 years are able to recognize their religion, practice worship, behave honest, helpful, polite, respectful, sportsmanship and so on, maintaining personal hygiene and the environment, knowing religious holidays, respecting (tolerance) the religions of others. So one of the efforts to develop children's ability to do worship is to instil a learning curriculum based on the Al-Qur'an education as a guide for human life. 
Children aged 5-6 years should be given stimuli from the environment, especially teachers and parents to teach children to read, study and memorize the Quran according to the predetermined curriculum, provided in the institution. Supported by the appropriate environment and facilities, children can channel their talents and abilities to continue to be stimulated and trained to be able to memorize Al-Quran and carry out sunnah in accordance with Islamic teachings from an early age. The very early age of children is not easy for children to memorize the 30th juz, but children who go to PAUD IT Sunnah An-Najah when they graduate have the advantage of being able to memorize surah in the 30th juz which consists of 37 chapters. The use of the right method for memorizing activities at school will greatly determine the success of learning.

Another hope that parents and teachers want is that children who are able to instil Islamic values from an early age can be used as a guide for children's life in forming good personalities and morals by starting with stimulation, understanding and a good environment. Increasing demands and the times make parents and teachers must work together to provide a complete foundation and capital from all aspects of life so that children are able to adapt themselves in the future. With the many influences that enter from all aspects of science and technology, early childhood will be very easy to fall into if it is not based on the cultivation of good religious values. In accordance with the opinion of Purnamasari [8] that character education can not only transfer knowledge or train certain skills. Character education requires a process, modelling, and conditioning or culture in the environment of students in the school environment, family, or community environment. Character education in the Qur'an needs to pay attention to the importance of cultivating a commendable moral dimension (akhlakul karimah).

So that the key to the success of a country lies in its human resources, so that early childhood at the golden age stage must be guided to learn the Koran, it is not only mandatory but must be practiced in everyday life. This is what teachers do by teaching early childhood to live a life in accordance with Islamic teachings.

\section{METHOD}

This research uses qualitative phenomenological research method with descriptive type which aims to analyse a social phenomenon and the perception of a person and group. Phenomenology was chosen because in this study the objective was to analyse the implementation of the Al-Qur'an education-based curriculum in PAUD IT Sunnah Annajah. According to Purnamasari [8] Descriptive qualitative research is a comprehensive description and explanation of various aspects by collecting the deep meaning of a unique phenomenon.
Data collection techniques used in this research are observation and interviews which aim to obtain opinions, perceptions, feelings, knowledge, experiences and information regarding the implementation of the AlQur'an-based curriculum through interviews with 2 teachers who teach the Qur'an. an. The data that researchers have obtained were analysed using data reduction, data presentation and drawing conclusions.

\section{RESULT AND DISCUSSION}

made, the researcher conducted interviews with a curriculum teacher and a tahsin teacher or Al-Qur'an teacher. PAUD IT Sunnah Annajah, Takengon City, Central Aceh District uses the 2013 curriculum by filtering programs according to schools, but not completely. However, if they can be fulfilled, such as developing aspects of children's art, schools choose aspects of art such as drawing and colouring, because schools do not allow children to sing, listen to music and dance. The school uses the 2013 curriculum but is adapted to the concept of this school, namely As-Sunnah. Another curriculum used in PAUD IT Sunnah Annajah uses a composition by Ustad Ali Akbar which combines a play centre on themes with $75 \%$ more emphasis on the Al-Qur'an and As-Sunnah.

As-Sunnah is used in regulations such as children behaving, such as the way children make decisions according to the concept of As-Sunnah with a focus on children's manners and morals. As-Sunnah is included in every concept of children playing, for example a picture book that is blindfolded including the sunnah because it cannot resemble a animate creature, another example of eating prayer in kindergarten in general is Allahuma bariklana, in PAUD IT Sunnah Annajah only Bismillah, because its sunnah. That is what distinguishes it, meaning that the sunnah is a pure way, desire, commandment from the Prophet.

The aim of the PAUD IT Sunnah Annajah school is to implement this curriculum so that in an effort to realize the vision and mission of the school, it can create a generation of Al-Qur'an memorizers who believe and have faith in Allah SWT, love the Sunnah of Rasulullah SAW, have noble character, are intelligent, active, independent and achievement. Equalizing perceptions between teachers and parents in an effort to make pious and sholeha children memorize the Qur'an, such as small differences in schools where children are prohibited from listening to music and at home, children are prohibited from watching television and at home are allowed to. Then, in order for thoughts and understanding between parents and teachers for the success of the child, because the child will ask why the child is allowed at home and at school is prohibited. So that arises in his thinking that there are pleasant places and unpleasant places, at school there are many restrictions and at home there are no 
restrictions. Therefore, the school's efforts to equalize these perceptions are by doing parenting.

Parenting is carried out once a month, schools always take a theme that connects children's education with school regulations, from an Islamic point of view how children's education is, then from child psychology how the development of children aged 5-6 years and according to their development. This is done so that parents keep abreast of and meet the growth and development needs of their children and there are no mistakes in education. Avoiding differences of opinion between parents who do not understand their children, what about the parents' expectations that their children's abilities are the same as other children being able to memorize the 30th juz Parents cannot force their children, because each child has different abilities. So that parenting is carried out with the aim that parents and schools understand more about children.

The application of parenting results in school is when the child is at home so that parents do not force the child to add to their memorization, but only muroja'ah (repeating), so that the next day the child can be given a new memorization and can achieve the target. The target for children aged 5-6 years is not too high, but the teacher hopes that the children's memorization is of good quality. Not just memorizing, the quality of memorization is good when people read wrong, the child knows what kind of right it is. In accordance with the vision and mission of the school, creating a generation that loves the Qur'an and is close to the Qur'an.

The learning process of reading Al-Qur'an in PAUD IT Sunnah Annajah has its own method which is different from other schools. At school, children learn in the Talaqqi way (reading Al-Qur'an in their own way dealing with parents or teachers). Without forcing children to add memorization at home, parents and children can modify strategies and methods so that children get used to adding to their memorization at home, such as repeating the child's favourite surah and repeating the child's rote before going to bed with the aim of making the child remember it to his subconscious to fall asleep. We are called upon to imitate the characters (morals) of Allah SWT, which is to teach the Al-Qur'an this is a noble activity because it is part of the effort to imitate the character of Allah SWT.

The best education given to children is Al-Qur'an education, because Al-Quran is the symbol of Islam's most basic and essential position. Through the provision of Al-Qur'an education to children, parents will receive blessings and glory from the holy book. Providing AlQur'an education to children is part of upholding the values of Islamic spiritualism. Rasulullah SAW, who has a mission to teach the holy book Al-Qur'an, calls and encourages parents not to forget to educate their children to read the Al-Qur'an when they are old enough. Educating and teaching the Qur'an are the main rights and obligations of children that must be fulfilled as soon as possible by their parents. This means that as long as the parents have not fulfilled it to the child, while the child is old enough and the parents themselves are capable, the parents will sin because they have not fulfilled their rights and obligations. When parents are absent due to other obstacles, parents must continue to carry out their obligations to continue providing Al-Qur'an education to children

Based on the curriculum used, the strategies adopted by the teacher in the classroom must always be directly related to concrete learning. The teacher must consistently add memorization for each child. One day one verse at least memorization that the child brings home, is not forced to target early childhood but the routines and habits that are given will make children accustomed to adding to their memorization every day.

After finishing learning the teacher gives instructions to the child to repeat the memorization on the previous day. The teacher gives instructions by saying the name of the surah according to the notes on the child's tahsin connecting book. Then the child repeats his memorization according to the direction from the teacher. After the child follows or imitates the teacher's reading well, the teacher asks the child to repeat it again until the child feels that he has memorized the verse. The teacher does not convey a new verse if during the talaqqi (repeating independently) the child is still not fluent in pronunciation. Then the teacher repeats the unfinished material in the same way on the other memorization material. As long as the children deposit their memorization, the teacher continues to correct the children's memorization so that there are no more mistakes.

This activity occurs repeatedly during the memorization program, after the children's memorization activities carry out the learning process as is done in general, while still paying attention to activities that develop aspects that exist in the child and are combined with the school curriculum. Children continue to learn while playing like other PAUD institutions, but most importantly students are introduced to religion, such as the introduction of God is a fundamental need for children. Implementation of activities from other AlQur'an education-based curricula such as being able to practice the teachings contained in the Qur'an in everyday life and how to make the Al-Qur'an a life guide as well as a friend for early childhood.

\section{CONCLUSION}

A child is born in a natural state with all the potential that can be developed into talents and interests according to the colours given by their environment. Education as one of the environments intended to foster and guide early childhood so that they are able to become useful 
human beings for religion and the future of the Indonesian nation. The Qur'an-based curriculum at PAUD IT Sunnah Annajah provides material and religious learning starting from the things closest to the daily life of early childhood, how children should behave and behave, children are introduced to that Allah is their Rabb, Al-Qur'an as the basis and guide for life, and in the Sunnah curriculum children are required to practice the teachings contained in the Qur'an.

\section{ACKNOWLEDGMENT}

I would like to thank Mr. Rudiyanto for his inspiring questions, suggestions and input regarding the application of a Qur'an-based education curriculum which really needs to be developed until this paper is completed. Hopefully this article is useful in both academic and non-academic fields.

\section{REFERENCES}

[1] Abdurrahman A. Implementasi manajemen kurikulum pesantren berbasis pendidikan karakter. AT-TURAS Jurnal Studi Keislaman. 2018;4(2):279-297.

[2] Saifuddin A. Eksistensi kurikulum pesantren dan kebijakan pendidikan. Jurnal Pendidikan Agama Islam (Journal of Islamic Education Study) [Internet]. 2016;3(1):207-234. Available from: http://jurnalpai.uinsby.ac.id/index.php/jurnalpai/arti cle/view/45.

[3] Prabowo YA. Pengelolaan kurikulum dan pembelajaran berbasis pesantren di SMP. Manajemen Pendidikan [Internet]. 2016;11(1):8389. Available from: https://doi.org/10.23917/jmp.v 11 i1.1830.

[4] Anas AI. Kurikulum dan metodologi pembelajaran pesantren. Cendekia Jurnal Kependidikan dan Kemasyarakatan. 2012;10(1):29-44.

[5] Mushollin. Kurikulum Pondok Pesantren Muadalah. NUANSA Jurnal Peneliti Ilmu Sosial dan Keagamaan Islam. 2014;11(1):127-50.

[6] Suardi W. Pesantren dan pengembangan kurikulum kewirausahaan: Kajian pesantren Roudlotul Khuffadz, Sorong Papua Barat. INFERENSI [Internet]. 2012;6(2):205-226. Available from: https://doi.org/10.18326/infs13.v6i2.205-226.

[7] Nasir M. Pengembangan kurikulum berbasis madrasah. HUNAFA Jurnal Studi Islam [Internet]. 2009;6(3):273-300. Available from: https://doi.org/ 10.24239/jsi.v6i3.138.273-300.

[8] Purnamasari D. Pendidikan karakter berbasis AlQuran. Islamic Counseling, Jurnal Bimbingan Konseling Islam [Internet]. 2017;1(1):1-24. Available from: https://doi.org/10.29240/jbk.v1i1.2 33. 